A Journal of Culture, English Language, Teaching \& Literature ISSN 1414-3320 (Print), ISSN 2502-4914 (Online)

Vol. 17 No. 1; July 2017

Copyright (c) Soegijapranata Catholic University, Indonesia

\title{
Implementing Learner-Centered Teaching in an English as a Foreign Language (EFL) Classroom
}

\author{
Ardi Marwan \\ Politeknik Negeri Pontianak, West Kalimantan, Indonesia \\ email: ardirini@yahoo.com \\ Received: 06-12-2016 Accepted: 20-07-2017 Published: 11-08-2017
}




\title{
Implementing Learner-Centered Teaching in an English Foreign Language (EFL) Classroom
}

\author{
Ardi Marwan \\ ardirini@yahoo.com \\ Politeknik Negeri Pontianak, West Kalimantan, Indonesia
}

\begin{abstract}
This research was initiated following the widespread claim regarding the success of learner-centered teaching approach across all disciplines. It seeks to examine whether such a claim is true by implementing a theoretical framework of learner centered teaching in an EFL Classroom. A qualitative design involving a teacher of English and a number of learners from a vocational higher institution was used. The findings of this study overall proved that the implementation of this learnercentered teaching framework could make a difference in students' learning. Their learning became more meaningful, interesting and democratic. Apart from this positive change, it was identified that teacher's understanding of implementing this framework was still limited resulting in the inconsistency of implementing all aspects of learner centered teaching approach. This study could highlight issues unique to the context of this research but were not covered in the framework. It, therefore, produced an extended framework. Findings from this study can be used for teachers who are interested in implementing the learner-centered teaching approach.
\end{abstract}

Key words: English, learner-centered, approach, framework.

Abstrak: Penelitian ini dilaksanakan karena adanya klaim terkait dengan susksesnya pembelajaran (pada semua bidang ilmu) yang menerapkan pendekatan pembelajaran berfokuskan pada siswa. Berkaitan dengan hal tersebut, penelitian ini bermaksud melakukan pengujian terhadap kerangka pengajaran yang berfokuskan pada siswa sebagai pembuktian terhadap klaim dimaksud. Penelitian ini menggunakan desain kualitatif melibatkan seorang guru Bahasa Inggris dan beberapa mahasiswa pada sebuah institusi pendidikan vokasi. 
Secara keseluruhan, hasil penelitian ini membuktikan bahwa implementasi kerangka pengajaran berfokuskan pada siswa dapat memberikan sebuah perbedaan yang berarti terhadap pembelajaran siswa dimana pembelajarannya jadi lebih bermakna, menarik dan demokratis. Namun demikian, selain dari hasil positif ini, penelitian ini juga membuktikan bahwa tingkat pemahaman guru terhadap kerangka pengajaran ini masih terbatas sehingga mengakibatkan terjadinya inkonsistensi terhadap penerapan seluruh aspek yang ada pada kerangka pengajaran ini. Selanjutnya, penelitian ini juga berhasil mengidentifikasi isu-isu yang unik dimana isu-isu tersebut tidak termaktub di dalam kerangka yang ada. Oleh karenanya, penelitian ini berhasil membuat kerangka baru sebagai ekstensi dari kerangka yang sudah ada. Temuan dari penelitian ini dapat digunakan oleh guru yang tertarik untuk menerapkan pengajaran berfokuskan pada siswa di dalam kelasnya.

Kata kunci: Bahasa Inggris, focus pada siswa, pendekatan, kerangka.

\section{RESEARCH BACKGROUND}

The world of education including the arena of English learning and teaching (ELT) has long shifted the focus of its teaching approach from mostly teacher-centered classroom atmosphere or often claimed as conventional way of teaching to a more learner-centered teaching. The main reason for this change is mainly due to a belief that the latter teaching approach can accelerate the process of knowledge and skills gain. Putting it into an ELT setting, it is strongly believed that in a learner-centered classroom, students will "become committed to improving their English" and more importantly "different learning styles can be accommodated and students can help each other to develop their skills" (Jones, 2007, p. 40). Considering the benefits that students will gain from the application of learner-centered teaching, it is no longer a choice for English teachers particularly those working in the context of English as a foreign language not to apply this approach.

Research looking into the use of this teaching approach in ESL/EFL settings is also enormous (Horst, 2003; Jambor, 2007; Nakamura, 2005; Nonkukhetkhong, Baldauf K, \& Moni, 2006; Nunan, 1988; Tudor, 1996; Zohrabi, Torabi, \& Baybourdiani, 2012) and many looked into the issue within the school and academic university setting. In many countries 
vocational higher education is now getting a momentum. In Indonesia, for example, the government is now promoting the development of new vocational higher institutions or called polytechnic across all the provinces. However, research looking into the application of learner-centered approach in the EFL classrooms is still rare. In short, the success often claimed in the literature usually comes from school or university system. This paper seeks to bridge this gap by presenting information from research looking into the use of this teaching approach in a higher vocational education system.

The first part of the paper highlights the study background followed with the presentation of literature related to learner-centered teaching approach and methods used in this research. Then, findings of this study are presented under the aspects of learner-centered framework and are discussed in light of the learner-centered teaching literature. The last part of this paper presents the framework resulting from this study.

\section{REVIEW OF LITERATURE}

\section{A. Learner-centered teaching framework}

A decision made by an educational system or a teacher to shift the teaching mode from mostly teacher-centered to learner-centered requires adjustment to most pedagogical aspects including "balance of power, function of content, role of the teacher, responsibility for learning, and purpose and processes of evaluation" (Schiller, 2009, p. 370). Schiller citing Saulnier, Landry, Longenecker, and Wagner (2008) and Weimer (2002) provides a framework outlined using each pedagogical aspect mentioned above which can be referred to by whoever interested in implementing learner-centered teaching in their classrooms.

\section{Figure 1:}

\section{Learner-Centered Framework (in Schiller, 2009, p. 370)}

Balance of power: Power is shared by faculty and students. Faculties do not make all decision for students without student input. Power is usually redistributed to students in amounts proportional to their ability to handle it.

Function of Content: Content plays a dual function in learner-center teaching: establishing a knowledge base and promoting learning. Faculty should develop course content not to cover everything, but to develop learning skills and learner awareness. 
Role of the Teacher: Instructors guide and facilitate learning, not forcing the learning, by sometimes stepping aside from the center of classroom activities and empowering students to discover knowledge and learn from each other in an encouraging but controlled learning environment.

Responsibility for Learning: Faculty should aim to create environments with fewer rules and requirements, which are conducive to learning, to encourage students to learn effectively, and to support the learning efforts of others. Students are motivated to build autonomy and responsibility in learning and receive timely feedback from faculty.

Purpose and Processes of Evaluation: Learner-centered methodology deploys a variety of assessment items. Instead of using a single grade as the sole evaluation tool, faculty should use evaluations to enhance students' potential to promote learning and to give them opportunities to develop self- and peerassessment skills. Evaluations and assessment should be less stressful and motivate students to reinforce their knowledge.

Having seen the framework, it can be argued that the overall focus of teaching is on giving a lot of opportunities to learners to experience learning. Such a teaching approach is seen by Meece (2003) as a way to help learners become an active knowledge constructor. In short, the underlying belief is that this approach enables learners to achieve their learning objectives.

\section{B. Teaching English using learner-centered approach}

Jones (2007) highlights some descrpitions as to how to teach English four skills using this approach. In teaching reading for example, teachers can facilitate students to comprehend reading text through discussion activities where they can help one another and share ideas. But, Jones reminds that when teaching reading, teachers are suggested to instruct learners to read the text before the start of the lesson. By doing this, much time can be saved and discussions can run more effectively and enjoyably. Then, teaching listening too needs to be directed towards learner-centered activities. While a few of listening-related activities such as listening to the tape, as Jones asserts, can only be done as an individual activity, many can be done within the pair or group work context. In other words, individual activities should be minimized. By so doing, teachers can facilitate learners to perform active learning (e.g., through exchange of views with peers). 
As for listening, writing can also be best learnt by learners through this learner-centered teaching approach. In Jones' views, the actual writing (e.g. writing an essay, a paragraph, etc) should take place at home or should be given as homework. The classroom activities for writing should again be carried out in the form of discussion activities. Such activtivities can include such things as brainstorming and mapping ideas."The big advantage of this student-centered approach to writing is that each writer knows who his or her reader will be, and can write to please them" (Jones, 2007, p. 34). Lastly, speaking is the skill which takes most of English learning activities in this learner-centered environment because, as Jones noted, speaking actvitities of "discussions are typical of any student-centered classroom" (p. 30). Such activities are, of course, not only limited to only question and answer (QA) activity but also can include tasks like role play, problem solving, pair work and group work. Overall, teaching English should be directed to enable learners to experience active and enjoyable learning.

Nonkukhetkhong et al., (2006) performed a case study looking at the implementation of learner-centered teaching approach at five Thai public secondary schools. Five English teachers in these schools were observed and interviewed about their experiences in teaching English using this approach. Reseachers of this study concluded that the pratices of learner-centered approach were not as successful as expected. Teachers experienced confusion about how they should properly apply this teaching approach in their classrooms. It was found out that the root of the problem was due to the absence of professional development that could support teachers attain necessary skills to effectively deliver learner-centered teaching in their English classrooms. Overall, having learnt the case, Nonkukhetkhong et al., then put forward an understanding that,

There are contextual factors that directly impacted on the implementation of the learning reform policy that illustrate that what may be appropriate to implement in other global contexts may not be equally successfully in particular local situations. (p. 8)

\section{METHODOLOGY}

This study was carried out using a qualitative research design in which the aim was to answer the following research questions: 
Volume 17, Number 1, July 2017, pp. 45 - 59

1. How well can learners study English speaking skill in a learner-centered classroom?

2. What are the challenges faced by the teacher in implementing five aspects of learner-centered framework?

3. How do learners perceive their learning of English with and without the use of learner-centered approach?

\section{A. Research site and participants}

The study took place at an Indonesian Polytechnic where the reseacher currently works as an English teacher. One class of students consisting of 25 people majoring in Information and Technology (IT) currently sitting at semester 4 were involved as the participants. These students learn English for four semesters from the total of six semesters they have to complete throughout their diploma 3 study. A fellow English teacher handling the class was also invited to become the participant of this research.

\section{B. Procedure}

This study tried out the use of LCTF for enhancing students' speaking skill. So, all learning activities were directed towards this productive skill. Four times teaching were performed where the teaching time was around 90 minutes. The researcher strictly followed the framework of learner-centered teaching as cited in Schiller (2009). With regard to function of content for instance, the teacher collaborated with the participants. Prior to teaching, the teacher showed the materials to the participants and asked them if they were happy with the materials particularly in terms of the topics to be discussed and level of difficulty. Then, concerning the role, the teacher acted as a facilitator to ensure that effective learning where the focus is on learners would take place. Principally, the processes of teaching and learning were undertaken in accordance with learner-centered teaching paradigm.

\section{Techniques for collecting and analyzing data}

Observation and semi-structured interviews were used as the means for data collection. Teaching and learning activities happening during this action research study were video-taped for detailed check. All activities were carefully observed and analyzed using the five aspects written in the learnercentered framework (see figure 1). Notes were made while observing or viewing the video for the purpose of accurate analysis. 
Then, interview questions which were developed by considering the aspects in learner-centered framework were also used to hear the voices of the participants concerning their teaching and learning experiences in a learnercentered classroom atmosphere. Five participants were carefully selected from around 25 students involved in this study. The selection was based on the results of the video view on action teaching. Participants showing unique actions (e.g. showing enthusiasm, lack of interest, etc.) were considered to be recruited for interview. The English teacher performing teaching with learner-centered teaching framework (LCTF) was also observed and interviewed. All the participants were notified that their participation was voluntary and their credentials would not be disclosed in the research report as codes would be used. To analyze the interview data, the transcripts were carefully checked and observed to search for common themes.

\section{FINDINGS AND DISCUSSION}

This study reported the findings from speaking classroom activities and discusses them in light of the literature. To manage the analysis work, the five aspects of learner-centered teaching framework (LCTF) (balance of power, function of content, role of the teacher, responsibility for learning, purpose and processes of evaluation) were used as the main themes.

\section{A. Balance of power}

Data from observation and interviews suggest that learners of this study could feel the benefit of teacher's use of LCTF for maximizing their English speaking learning. It could be well seen that they dominated most of the classroom activities. This is, as the literature suggests, the atmosphere that they should be provided with because only through which they can undergo an effective learning (Jones, 2007; Nakamura, 2005; Nunan, 1988). With regard to the first aspect of LCTF (balance of power), it could be argued that the English teacher of this study was quite successful in managing the sharing of power with their students. Prior to delivering the lesson, he informed the students about what they would learn in the next 90 minutes. A number of possible topics (education, friendship, jobs, hobby, and sport) and activities (pair work, small group discussion, role play and class presentation) were brought into students' attention and they were given the opportunity to choose their preferred topics and learning activities. The interview data, however, revealed that the teacher found this part of teaching was so 
challenging because very often students came up with different topics of preference. As he said:

Inviting my students to decide what topic to be discussed and what type of learning activity to be performed in a classroom is a challenging one. When doing this, I rarely found that all students could agree on one topic or activity only. So, it is rather difficult to entertain all students' expectation.

Jones (2007) does not see the case experienced by the teacher of this study as something that should be worried about. It is the art of applying this approach where teachers need to be sensitive towards students' learning needs. But, Jones may consider the approach undertaken by the teacher is a bit off track. He could have done other ways in identifying learning needs of his students and he is right that it is not possible to entertain individual student's topic preference. As Jones asserted:

A student-centered classroom isn't a place where the students decide what they want to learn and what they want to do. It's a place where we consider the needs of the students, as a group and as individuals, and encourage them to participate in the learning process all the time. (p. 3)

Obviously, the underlying philosophy of learner-centered approach is to make effective learning happens and students can acquire the language being learnt successfully (Jones, 2007; Meece, 2003; Nakamura, 2005). Despite the improper way used by the teacher when trying to hear from his learners regarding the topic they wanted to discuss in the classroom, the students saw it as a brilliant way of teaching. They could feel that they were well respected by their own teacher in a sense that they could say their words in a decision making process. The learning of English could be so democratic and the picture of an authoritative teacher was no longer there. Unlike before particularly when learning English at schools, teachers were so unfriendly. They were coming to the class for transferring the content of the textbooks to them through one way communication approach where they talked most of the time in the class. In other words, students were not regarded as teachers' learning partner and they argued that if they had been exposed to the learner-centered approach, they would have spoken an excellent English by now. 


\section{B. Function of content}

This study proved that this part of LCTF was quite problematic for the teacher since he was dealing with students with different level of English proficiency. A few of his students could demonstrate a quite fine level of English or equivalent to the score of 450 in paper-based TOEFL, while many others were in the range of $310-380$. He was often confused when it came to a point where he should make a decision about the course content that should be brought into the classroom. He argued that the case would be different if his students possessed a similar level of English proficiency. But, he pointed out that despite the matter, he should not leave the essence of introducing LCTF to their students, that is, to make them become active learners of English. For this reason, rather than spending so much energy on thinking about the most appropriate learning materials for all their learners, he preferred to deal with such a matter through learning activities which could engage all learners. The observation note also highlighted some good work of this teacher when trying to make all their learners get involved in almost all learning activities. He particularly paid attention to students who tended to be passive in their learning. Often, he invited this type of students to give their ideas or share their answers to the given questions or tasks.

Realizing that the content of course materials was not easy for some students in his class, the teacher mix-grouped his students where he placed one or two good students in a group with a few other poor students. For instance, one of the topics agreed between the teacher and students was education. The teacher then asked each group to discuss the chosen topic for 20 minutes. Below are some excerpts noted during a discussion performed between two students (a smart student, James and an average one, Brown).

James : hi all, is education important in your life?

Brown : important

James : so, for you, it is important.

Brown : yes, it is important

James : Can you tell me your reasons, Brown?

Brown : I think without good education, I will not life well. 


\section{Celt: A Journal of Culture, English Language Teaching and Literature,}

Volume 17, Number 1, July 2017, pp. 45 - 59

James : Do you mean you will not live well

Brown: yes, that is what I mean.

Narratives of the interview with the teacher confirmed that such an approach was meant to help passive learners (i.e. usually those with poor English) to be more active in their English learning. The observation data indicated that this approach was successful in making his students engaged actively in learning activities. However, there was a unique atmosphere which could be noted during the conduct of small group activities. It could be identified that students with good English often played a role as a learning facilitator for the less able students. But, they spent little time for their own learning in accordance with their level of English. Apart from this, overall the mission to make most learners become actively involved in learning activities could be achieved through mixing good students and less able ones in small group works. In spite of this little problem, assigning students to do a group work is a good way of teaching as it allows them to talk in English more frequently (Nunan, 1988) and in Frank's views (in Richards \& Rodgers, 2001), learners can acquire a language effectively if they are given the chance to use it actively in the classroom.

\section{Role of the teacher}

The role the teacher plays can be partly seen from the teaching approach he performed in the sections of balance of power and function of content above. It could be seen that he was striving to limit his talking time by making his students dominate the class activities, for example, through small group discussion. This also means that he was trying to be an effective classroom manager whose task is to engage all learners in classroom learning activities, for example by grouping smart learners with other less smart ones, and avoid the class being dominated by a few learners only. When interviewed about this matter, he explained that the only main thing that he had in mind when teaching his class with the learner-centered framework was to make sure that all his learners could engage in active learning. He also added that:

English is a language in that it can only be mastered through frequent practices. Obviously, if learners are not given the opportunity to frequently use it, their good mastery of English will only be a story. In other words, it will never be a reality. 
When asked about the concept of teacher's role in learner-centered framework which says that "instructors guide and facilitate learning....and empowering students to discover knowledge and learn from each other in an encouraging but controlled learning environment" (in Schiller, 2009, p. 370) the teacher explained that the concept could be well materialized through group activities. For example, "when asking the less able students to work in small groups with the smart ones, I could make the usually passive learners be more active in their learning with the help of their smart colleagues". However, when questioned about the unique atmosphere identified during the observation regarding the chance for smart learners to experience learning suitable with their level of English, the teacher admitted that this was something he did not anticipate prior to his teaching using this framework. He also pointed out that his teaching could only be benefitted mostly by the less smart learners and little for the smart ones in terms of the addition of new knowledge for them.

Nunan (1999) is not in agreement with the teacher of this study with respect to the idea that smart learners will only gain little knowledge from this learner-centered approach. They will certainly gain a lot if the teacher is sensitive to their learning need. As he argued, "key decisions about what will be taught, how it will be taught, when it will be taught, and how it will be assessed will be made with reference to the learner" (1999, p. 11). Obviously, in the context of this research, the teacher should also consider the learning need of those smart learners in that there may be a time given to them to stay as a group and provided with a task suitable for their level of English. The key issue here is clear then that teachers have to play a role as a learning facilitator for all learners.

\section{Responsibility for learning}

The teacher admitted that this LCTF teaching approach could work well (in terms of the responsibility for learning) in his class mainly because the autonomy given to him to manage his class starting from the planning to the evaluation of learning. In other words, the institution does not provide a certain level of achievement that students should acquire. This, however, does not mean that the management does not care with the students' learning attainment. They do so partly because a six-year English learning experienced by learners (from lower to upper secondary school) does not give a positive significant impact to their English proficiency despite the fact that all the students can successfully pass the nationally held English exam. Many 
of them even could not converse using simple English when they started their education in this vocational higher education.

He, however, claimed that such an autonomy was put in place with a consequence. Teachers should be creative in their teaching. Being creative also means that they need to optimize their students' learning because only through which learners can acquire English well. He added that although the management did not require students to undertake a standardized English test to assess their learning progress and achievement, they could still check if the learners succeeded in their English learning through speaking in English with some of the randomly selected students. Thus, the pressure to perform a quality teaching was still there. When applying this last aspect of learner centered framework into his class, he contended that all his learners were so enthusiastic. The class was so busy with talks and discussions in English. Even the ones with low English level could show off their English.

\section{E. Purpose and processes of evaluation}

Data of this study showed that this is the aspect of learner-centered framework that the teacher was so good at doing. He did not use a single assessment tool to evaluate the learning outcome. Instead, he evaluated it through a variety of assessment tools. In one occasion, for example, he used peer-assessment approach where he asked the certain students, while doing a group activity, to ask other students questions (in English) about the topic being discussed. He was making some notes about the strengths and weaknesses of students' speaking while observing them doing the question and answer activity. When questioned about the reason for doing so, he claimed:

I particularly like this type of assessment since it allows me to monitor the progresses of my students' learning effectively. The good thing about it is that the students do not realize that they are being evaluated so they can act naturally. In other words, they not like in a tense condition just like in an actual test situation.

In another occasion, he requested his students to do a pair work talking about their own chosen topic. Each pair should speak for about 15 minutes and have their conversation recorded. Knowing that such an activity would create noisy if done in the class, the teacher then asked the students to do it outside the class. He instructed them to do it in a quite area around the 
campus. Then, the students were requested to briefly talk to the class about their conversation activity and hand in their recording to him for assessment. "This activity allows me to accurately assess the students' speaking progresses because I can replay the recording as often as I want" he said during an interview. Despite the strength of this type of assessment, he admitted that he sometimes had a problem with the time that he had to spend to assess the students' recordings. He said that he required more time for this one than the time he would spend for another type of assessment.

\section{F. Issues identified during the fieldwork but uncovered in the current theoretical framework}

Issues which could be identified in the data that seem not to have a direct link with the five aspects of learner-centered framework include the importance of professional development for teachers, the provision of quality teaching and learning resources, regular monitoring, and commitment from management. The first three issues were addressed by both the teacher and students during the interviews while the last one was mentioned by the teacher.

\section{Figure 2:}

The extended framework for implementing learner-centered teaching

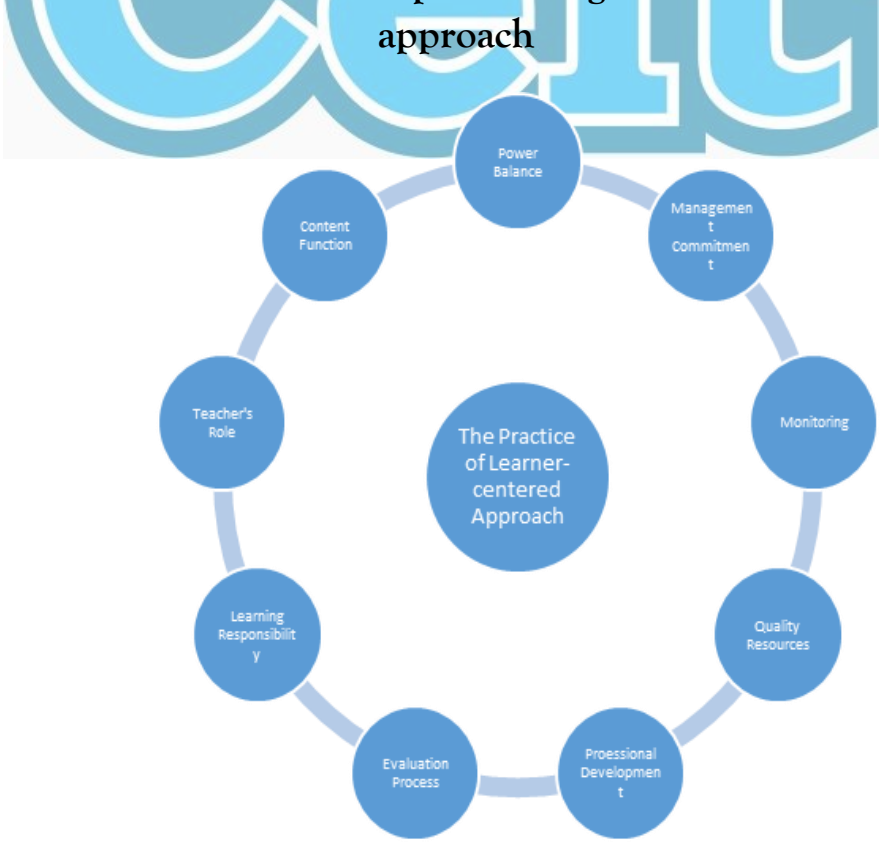


The emergence of these context-specific issues generates the creation of new learner-centered framework meaning that the current investigated vocational higher institution may not attain success in implementing the learner-centered teaching approach if it only uses the above said theoretical framework. The new framework, therefore, should contain the aspects of professional development, quality resources, monitoring, and commitment from management (see Figure 2).

\section{CONCLUSION}

The present study examines a learner-centered framework into an English classroom at a vocational higher institution in Indonesia. Although such a theoretical framework is used as a tool to implement learner-centered teaching, information identified during the fieldwork which has an influence on the success of teaching and learning with this approach is well regarded in this study. As a result, an extended version of framework is produced and is more suitably used by this vocational higher institution. This process of new framework creation shows that this study is not driven entirely by the theoretical framework. Rather, it also takes into account other data-based emerging issues which could significantly impact on the implementation success. So, this research is powerful as it tinks theory to practice and vice versa. This study overall concludes that a theoretical framework may be used as a guideline or reference in implementing change in an organization but its use should not close the opportunity for the individuals involved in the change process and whose voices are being investigated in a study to disclose issues which they think to have a significant impact on the change outcome. This is necessary to be done since the framework may be produced as a result of investigation of a case happening in an organization of a certain system and thus it may not consider issues existing in another system.

\section{REFERENCES}

Horst, S. (2003). Using Student-Centered Activities to Increase English Language Learners' Involvement and Achievement in Literacy. Retrieved 13 March 2014, from www.gse.gmu.edu/assets/ docs $/ \mathrm{lmtip} /$.../S.Horst.doc 
Jambor, Z. P. (2007). Learner Attitudes toward Learner Centered Education and English as a Foreign Language in the Korean University Classroom. (MA Dissertation), The University of Birmingham, Birmingham.

Jones, L. (2007). The Student-Centered Classroom. Cambridge: Cambridge University Press.

Meece, J. L. (2003). Applying Learner-Centered Principles to Middle School Education. Theory into Practice, 42 (2), 109-116.

Nakamura, K. (2005). Creating a Learner-centered Communicative Classroom for Student Teachers. The Journal of the Institute for Language and Culture, 9(1-20).

Nonkukhetkhong, K., Baldauf K, R., B., \& Moni, K. (2006). Learner Centeredness in Teaching English as a Foreign Language. Paper presented at the 26 Thai TESOL International Conference, Chiang Mai.

Nunan, D. (1988). The learner-centred curriculum: a study in second language teaching. Cambridge: Cambridge University Press.

Nunan, D. (1999). Second Language Learning and Teaching. Boston: Heinle and Heinle Publishers.

Richards, J., \& Rodgers, T. (2001). Approaches and Methods in Language Teaching Cambridge: Cambridge University Press.

Schiller, S. Z. (2009). Practicing Learner-Centered Teaching: Pedagogical Design and Assessment of a Second Life Project. Journal of Information Systems Education, 20, 369-381.

Tudor, I. (1996). Learner-centredness as language education. Cambridge: Cambridge University Press.

Weimer, M. (2002). Learner-Centered Teaching: Five Key Changes to Practice: Jossey-Bass.

Zohrabi, M., Torabi, M. A., \& Baybourdiani, P. (2012). Teacher-centered and/or Student-centered Learning: English Language in Iran. English Language and Literature Studies, 2 (3), 18-30. 